
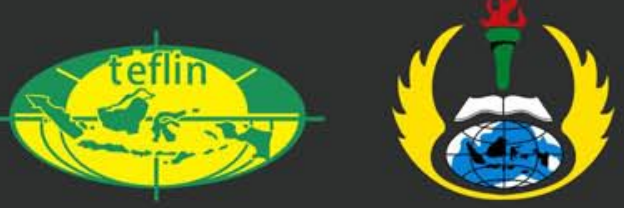

THE ASSOCIATION FOR THE TEACHING OF ENGLISH AS A FOREIGN LANGUAGE IN INDONESIA \& ENGLISH LANGUAGE EDUCATION DEPARTMENT - UNIVERSITY OF PGRI ADI BUANA SURABAYA

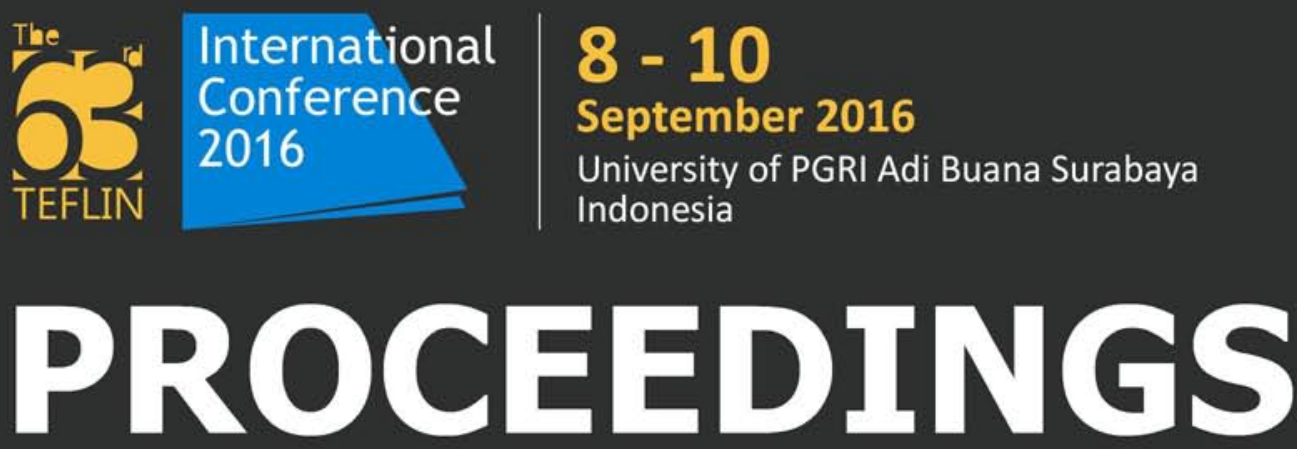

"Creativity and Innovation in

Language Materials Development and

Language Teaching Methodology

in Asia and Beyond" 

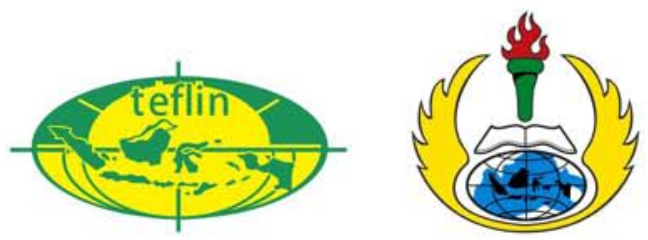

THE ASSOCIATION FOR THE TEACHING OF ENGLISH AS A FOREIGN LANGUAGE IN INDONESIA \& ENGLISH LANGUAGE EDUCATION DEPARTMENT - UNIVERSITY OF PGRI ADI BUANA SURABAYA

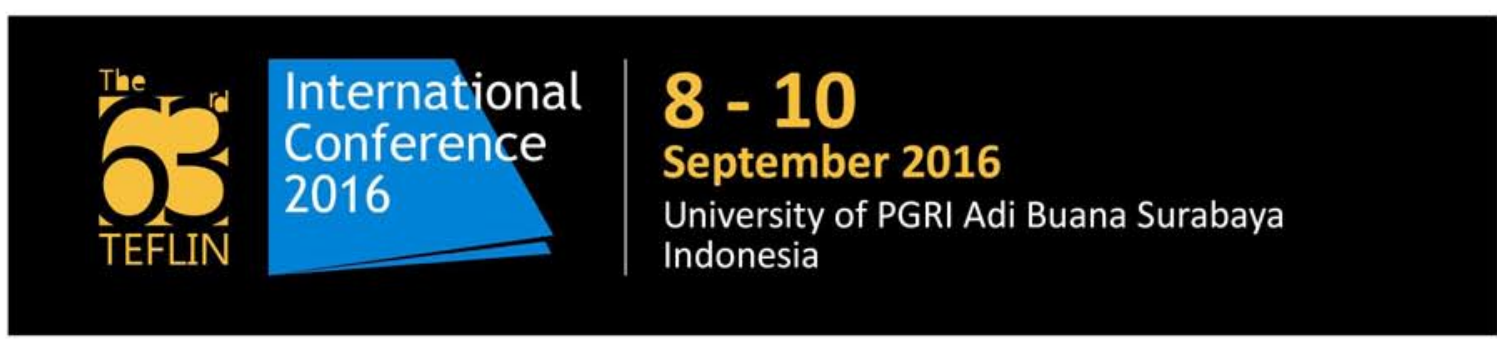

\section{PROCEEDINGS}

"Creativity and Innovation in

Language Materials Development and Language Teaching Methodology in Asia and Beyond" 


\section{FOREWORD}

Today's language teaching needs creative and innovative ways to design and use language materials that learners can exploit to expand their language repertoire and develop their language ability as they engage with a myriad of texts and activities or tasks inside and outside the classroom. With this in mind, the $63^{\text {rd }}$ TEFLIN Conference brings up a central issue on "Creativity and Innovation in Language Materials Development and Language Teaching Methodology in Asia and Beyond." Drawing on this central theme, the conference develops several sub-themes: a) the development of language materials for content-based instruction, b) the development of language materials for text-based instruction, c) the development of language materials for genre-based Instruction, d) approaches and methods in language teaching, e) techniques and procedures in language teaching, d) technology-based language instruction, f) the role of technology in innovation in ELT methodology, g) the role of technology in language materials development, h) creative writing in ELT (Literature-Based Language Instruction).

As an academic forum, the great focus is in its proceedings as the center of publication for its presenters. It is aimed at maximizing the value of the publication as the outcome of the conference. It is intended that the proceedings can be as a global publication. The quality of the proceedings as a means of publication in this year's edition should be improved. The committee has applied the system for abstract selection of which the criteria is the consistency with the conference's theme. Reviewers have the right to select the papers based on the abstract that have been submitted to the committee.

The coverage of the sub-themes for this year's conference is broadened to certain areas. Bear in mind that the main and solely theme of materials development for language teaching and methodology is not limited to certain topics. To cope with the central theme, some additional subthemes are offered to the conference's audience to write their research findings into expected academic paper. This year's papers which are selected to be presented in the conference reach more or less than 422 . There are more than 400 papers which will be published in proceedings. Other opportunities of publication are offered by TEFLIN Journal as well. For next year's edition, two papers have been selected out of the submitted papers. To add the chance of the conference's publication, some papers have been selected to be further reviewed for Scopus-Indexed publication. In addition, from papers are accepted by A Journal of Culture, English Language Teaching and Literature (Celt), Soegijapranata Catholic University Semarang to be published in the year of 2017.

The growing number of papers presented in the conference is indicating an increase in the need for publication of research findings. Therefore, TEFLIN's conference proceedings are entrusted to be an academic forum to share thoughts, reflections, experiences related to academic works for teachers, lecturers, researchers, educators who continuously write, present, and publish their academic works.

Finally, we would like deliver great appreciation to the organizers, presenters, writers, and all parties who have been contributing directly and indirectly to the publication of the proceedings.

Surabaya, September 2016

The Committee 


\section{LIST OF INTERNAL AND EXTERNAL REVIEWERS}

\section{INTERNAL REVIEWERS}

1. Endang Mastuti Rahayu

2. Ferra Dian Andanty

3. Nunung Nurjati

4. Dyah Rochmawati

5. Wahju Bandjarjani

6. Siyaswati

7. Salim Nabhan

8. Irfan Rifai

9. Hertiki

10. Fajar Susanto

11. Nukmatus Syahria

12. Joesasono Oediarti

13. Lambang Erwanto Suyyajid

14. Rikat Eka Prasetyawan

15. Rahmad Hidayat

16. Titah Kinasih

17. Endah Yulia Rahayu

18.Maslakhatin
(Adi Buana University)

(Adi Buana University)

(Adi Buana University)

(Adi Buana University)

(Adi Buana University)

(Adi Buana University)

(Adi Buana University)

(Adi Buana University)

(Adi Buana University)

(Adi Buana University)

(Adi Buana University)

(Adi Buana University)

(Adi Buana University)

(Adi Buana University)

(Adi Buana University)

(Adi Buana University)

(Adi Buana University)

(Adi Buana University)

\section{EXTERNAL REVIEWERS}

1. Abdul Ghani Abu

2. Mohamad Razak Abdul Karim

3. Aslam Khan Bin Samahs Khan

4. Noriah Talib

5. Fazlinah Binti Said

6. Rozanna Noraini Amiruddin Albakri (Institute of Teacher Education

7. Handoyo Puji Widodo

8. Ahmad Idris Asmaradhani

9. Herri Mulyono

10. Mukrim Thamrin

11. E. Sadtono

12. Gunadi Harry Sulistyo

13. Suparmi
International Languages Campus Kuala

Lumpur, Malaysia)

(University Pendidikan Sultan Idris Malaysia)

(Open University Malaysia)

(Institute of Teacher Education

International Languages Campus Kuala

Lumpur, Malaysia)

(Institute of Teacher Education

International Languages Campus Kuala

Lumpur, Malaysia)

(Institute of Teacher Education

International Languages Campus Kuala

Lumpur, Malaysia)

(Shantou University, China)

(Graduate School of English Education, IKIP Mataram, NTB)

(University of Muhammadiyah Prof. DR.

HAMKA)

(Tadulako University Palu)

(Ma Chung University, Malang)

(Universitas Negeri Malang)

(Maulana Malik Ibrahim State Islamic

University, Malang) 
14. Rina Sari

15. Achmad Farid

16. Veronica L Diptoadi

17. Anita Lie

18. Agustinus Ngadiman

19. Harto Pramono

20. Siti Mina Tamah

21. Ruruh Mindari

22. Luluk Prijambodo

23. Mateus Yumarnamto

24. Yohanes Nugroho Widiyanto

25. Agnes Santi Widiati

26. Fabiola D Kurnia

27. Flora Debora Floris

28. Salimah

29. Yerly A Datu

30. Rida Wahyuningrum

31. Rica Sih Wuryaningrum
(Maulana Malik Ibrahim State Islamic

University, Malang)

(Universitas Pesantren Tinggi Darul Ulum

Jombang)

(Universitas Katolik Widya Mandala)

(Universitas Katolik Widya Mandala)

(Universitas Katolik Widya Mandala)

(Universitas Katolik Widya Mandala)

(Universitas Katolik Widya Mandala)

(Universitas Katolik Widya Mandala)

(Universitas Katolik Widya Mandala)

(Universitas Katolik Widya Mandala)

(Universitas Katolik Widya Mandala)

(Universitas Katolik Widya Mandala)

(Universitas Negeri Surabaya)

(Universitas Kristen Petra)

(Universitas Airlangga)

(Universitas Surabaya)

(Universitas Wijaya Kusuma)

(Universitas Wijaya Kusuma)

\section{SETTING AND TYPESET}

1. Irfan Rifai

2. Catherine Sitompul

3. Salim Nabhan

4. Hertiki

5. Maslakhatin

6. Aryo Wibowo

7. Samsul Khabib

8. Armelia Nungki Nurbani

9. Lutfi Prahara

10. Abdul Ghoni

11. Ratna D Wiranti

12. Desi Priskawati

13. Dinda Dwiki Prasista

14. Ahmad Azzam Ridhoi

15. M. Ndaru Purwaning Laduni

16. Triana Mey Linda

\section{COVER}

Tantra Sakre 
LIST OF INVITED SPEAKERS

\begin{tabular}{|c|l|l|}
\hline No. & \multicolumn{1}{|c|}{ Name } & \multicolumn{1}{c|}{ Affiliation } \\
\hline 1 & Prof. Lesley Harbon & University of Technology, Sydney \\
\hline 2 & Dr. Lindsay Miller & City University of Hongkong \\
\hline 3 & Christine C.M. Goh, PhD & Nanyang Technological University, Singapore) \\
\hline 4 & William Little & $\begin{array}{l}\text { Regional English Language Officer, US } \\
\text { Embassy }\end{array}$ \\
\hline 5 & Dr. Willy A Renandya & $\begin{array}{l}\text { Nanyang Technological University, National } \\
\text { Institute of Education, Singapore }\end{array}$ \\
\hline 6 & Joseph Ernest Mambu, PhD & $\begin{array}{l}\text { Satya Wacana Christian University, Salatiga, } \\
\text { Indonesia }\end{array}$ \\
\hline 7 & Made Hery Santosa, PhD & $\begin{array}{l}\text { Ganesha University of Education, Bali, } \\
\text { Indonesia }\end{array}$ \\
\hline
\end{tabular}

\section{LIST OF FEATURED SPEAKERS}

\begin{tabular}{|c|l|l|}
\hline No. & \multicolumn{1}{|c|}{ Name } & \multicolumn{1}{c|}{ Affiliation } \\
\hline 1. & Dr Chan Yue Weng & RELC \\
\hline 2. & Payupol Suthathothon & Thai TESOL \\
\hline 3. & Ted O'Neill & JALT \\
\hline 4. & Colm Downes & British Council \\
\hline 5. & Lai-Mei Leong & MELTA \\
\hline 6. & Nicholas Millward & CamTESOL \\
\hline 7. & Sothearak Norng & CamTESOL \\
\hline 8. & Brad Hughes & University of Technology Sydney \\
\hline 9. & Dr. Aurora Murphy & University of Technology Sydney \\
\hline 10. & Dr. Neil England & University of Technology Sydney \\
\hline 11. & David Akast & British Council \\
\hline 12. & Ann Eastlake & British Council \\
\hline 13. & Michael Little & British Council \\
\hline 14. & Itje Chodidjah & British Council \\
\hline 15. & Aslam Khan Bin Samahs Khan & Institute of Teacher Education International \\
& & Languages Campus Kuala Lumpur, Malaysia \\
\hline 16. & Zoe Kenny & IALF Surabaya, Indonesia \\
\hline 17. & Wendy George & Aliansi Lembaga Bahasa Asing \\
\hline
\end{tabular}

\section{UNIVERSITY PRESS}

\section{ADIBUANA SURABAYA}

All rights reserved. No part of this book may be reproduced or transmitted in any form or by any means: electronic or mechanical, including photocopying, recording, or by any information stroge and retrieval system, whithout prior written permission from the writers. 



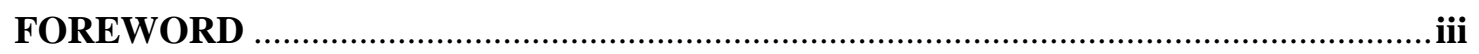

LIST OF INTERNAL AND EXTERNAL REVIEWERS ............................................. iv

LIST OF INVITED SPEAKERS AND FEATURED SPEAKERS …............................. vi

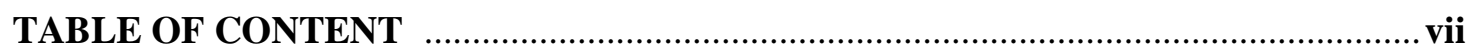

THE EFFECT OF THE DELAYED CORRECTION ON THE ACQUISITION OF PAST MORPHOLOGICAL INFLECTIONS BY L1-INDONESIAN-SPEAKING

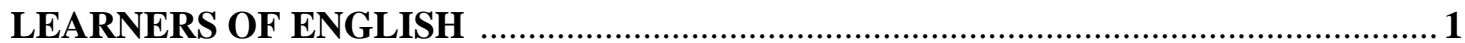

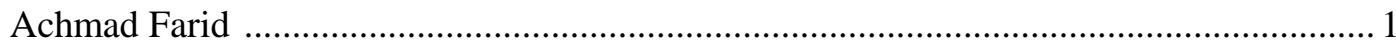

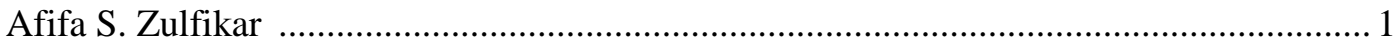

DEVELOPING “THE MYSTIQUE" GAME AS A MEDIUM FOR ENCOURAGING

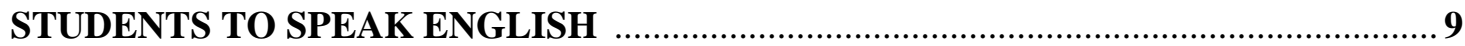

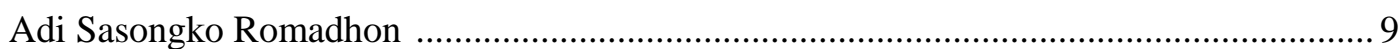

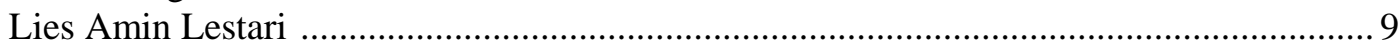

IMPROVED VOCABULARY COMPLEXITY OF THE SPOKEN UTTERANCES BY USING STRATEGY-BASED INSTRUCTIONS IN ENGLISH SPEAKING CLASS .... 17

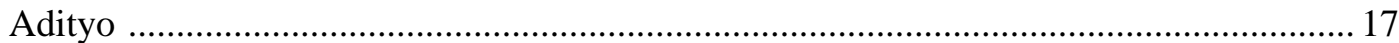

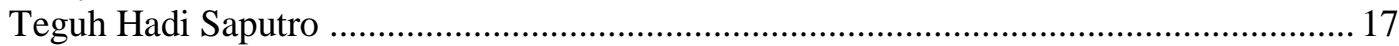

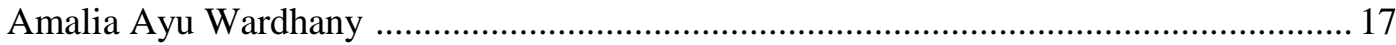

DEALING WITH LINGUISTIC PROBLEMS FACED BY MASTER'S STUDENTS

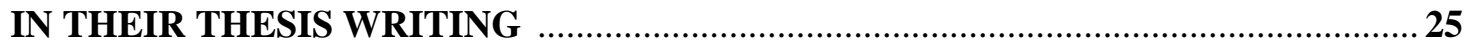

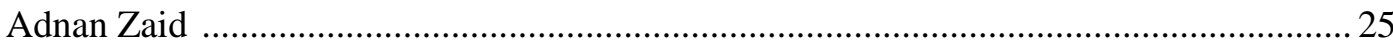

EXPLORING POSTMETHOD FRAMEWORKS FOR POWERFUL ENGLISH

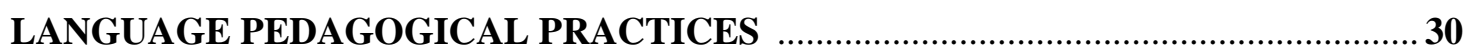

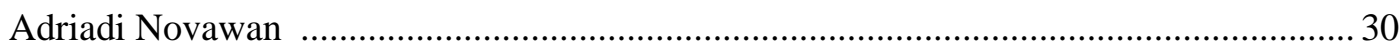

GAMIFYING DIGITAL ENGLISH GRAMMAR MATERIALS FOR THE SENIOR

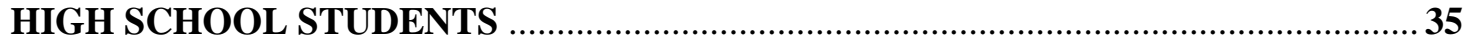

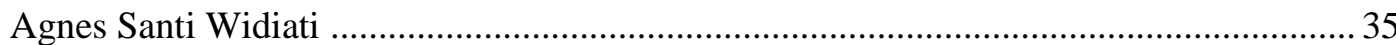

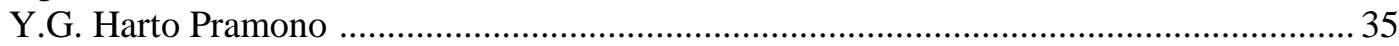

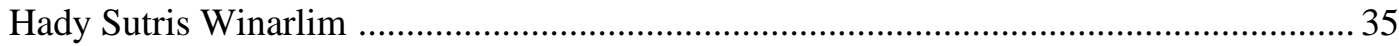

MEDIATING THE STUDENTS' ENGLISH ACQUISITION THROUGH TASKS AND INTERACTIONS: ANALYSIS ON "THINK GLOBALLY ACT LOCALLY",

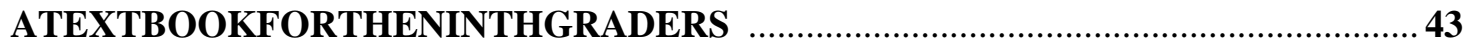

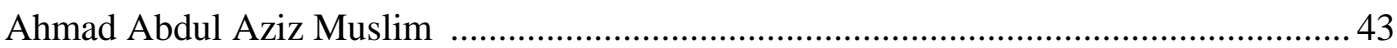

IMPROVING SPEAKING FLUENCY OF INDONESIAN ENGLISH FOR SPECIFIC PURPOSE STUDENTS BY USING SELF-VIDEO RECORDING …........................5 53

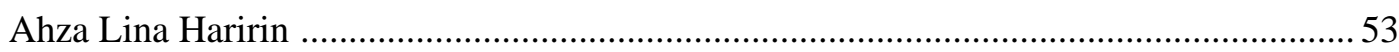

DESIGNING WEBSITE-BASED MATERIALS FOR SUPPLEMENTARY WRITING RESOURCES FOR JUNIOR HIGH SCHOOL STUDENTS .....................................59

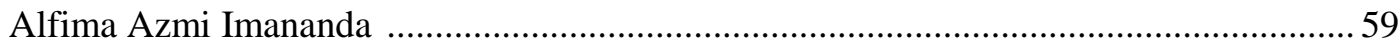

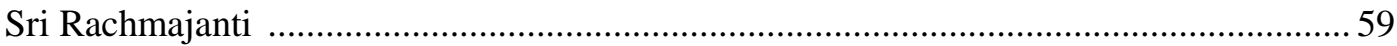

THE CORRELATION BETWEEN READING COMPREHENSION ABILITY AND READING HABIT OF THE SEVENTHSEMESTER STUDENTS OF STIENAS

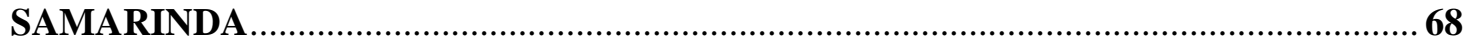

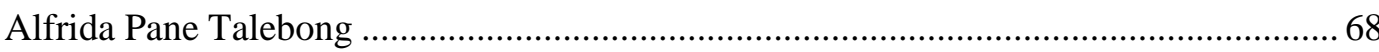


COMPREHENSIVE ENGLISH LEARNING THROUGH SPEECH COMMUNITY-

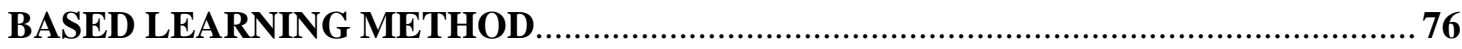

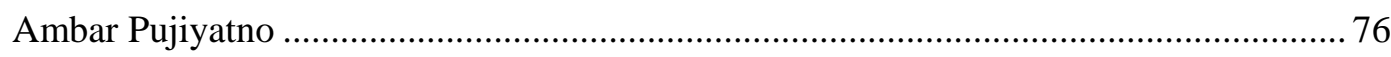

CONTRIBUTION OF MOTIVATION, LANGUAGE INPUT, AND MILIEU TO SECOND LANGUAGE ACQUISITION IN ENGLISH AS A FOREIGN LANGUAGE CONTEXT: AN EXPLORATORY PRELIMINARY CASE STUDY .............................82

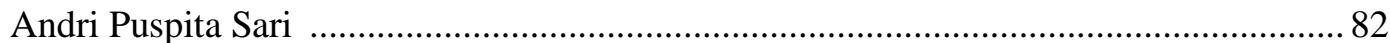

Gunadi Harry Sulistyo.

TEACHER'S CREATIVITY TO PROMOTE SECOND LANGUAGE ACQUISITION

TO MATCH INEVITABLE FIRST LANGUAGE ACQUISITION SUCCESS .............87

Andy

LEVERAGING TEACHER EXPERIENCE AND AUTONOMY IN BLENDED, INSERVICE TEACHER TRAINING.

EFL WRITING CURRICULUM IN A PRIVATE UNIVERSITY:AN EVALUATIVE STUDY USING A SYSTEMATIC APPROACH.

TEACHING ACADEMIC WRITING USING AUTHENTIC MATERIALS:

A CASE OF WRITING A RESEARCH ARTICLE ABSTRACT .

Anisa Pinatih

THE EFFECTIVENESS OF FLIPPED CLASSROOM SUPPORTED BY COOPERATIVE LEARNING TO IMPROVE STUDENTS' READING SKILL: A STUDY IN BRINGIN 1 SENIOR HIGH SCHOOL CENTRAL JAVA INDONESIA .. 123 Anjas Karuniawan

DESIGNING ESP MATERIALS FOR BIOLOGY STUDENTS

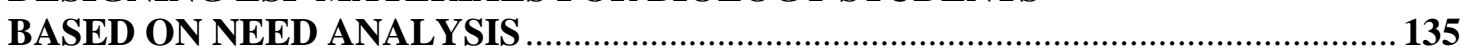

Annisa Maisaroh

ENERGIZING FOREIGN LANGUAGE STUDENTS IN ENGLISH SPEAKING CLASS

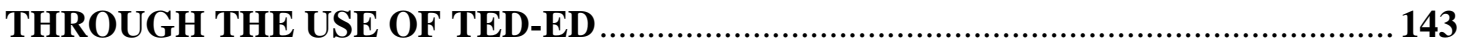

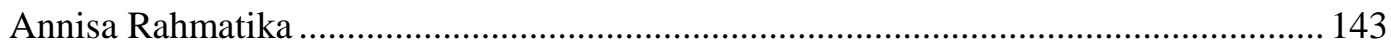

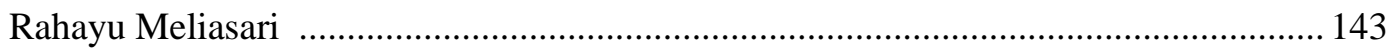

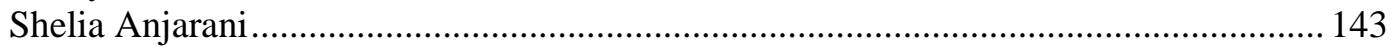

ENHANCING STUDENTS' SKILL IN ORGANIZING IDEA THROUGH GRAPHIC

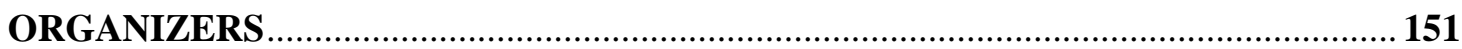

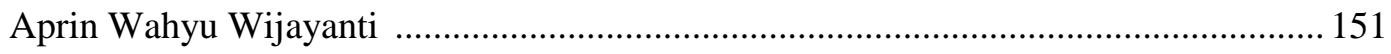

EMPLOYING WRITING PROCESS APPROACH IN DEVELOPING E-MODULE OF

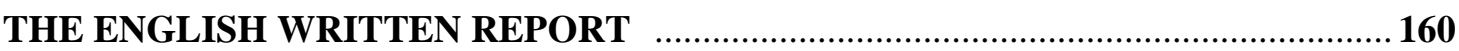

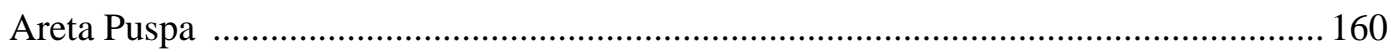

THE COMMON CLASSROOM TECHNIQUES USED TO TEACH ENGLISH IN

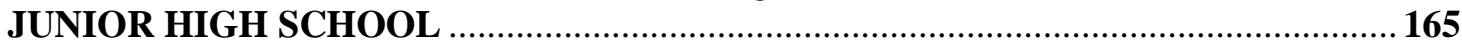

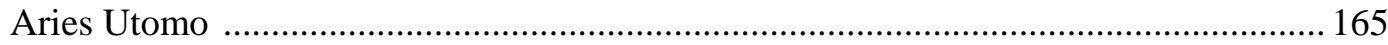

TEACHING ENGLISH FOR HEARING-IMPAIRED STUDENTS: AN EXPERIENCE AT SEKOLAH LUAR BIASA NEGERI TIPE B BLITAR, EAST JAVA .....................171

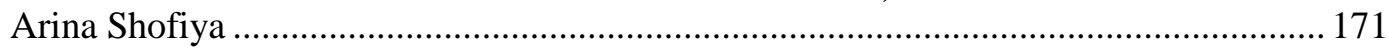

EXPLOITING STUDENTS WRITINGSKILL: A BLENDED LEARNINGIN

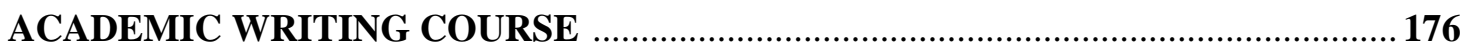

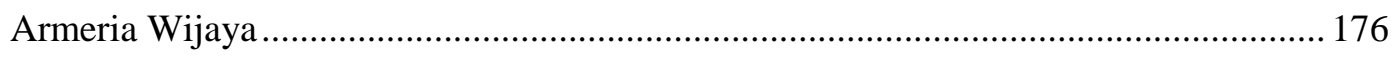


INTERPRETIVE ITEMS OF ENGLISH SEMESTER TEST COMPOSED BY JUNIOR HIGH SCHOOL TEACHERS IN PADANG IN 2014/2015 ACADEMIC YEAR ........... 181

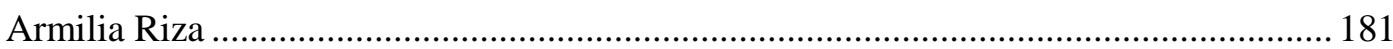

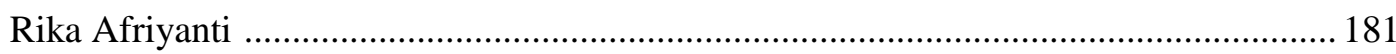

FACTORS IN ENGLISH COMMUNICATIVE COMPETENCE FOR MATH AND

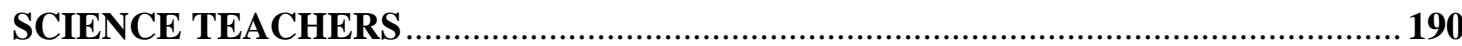

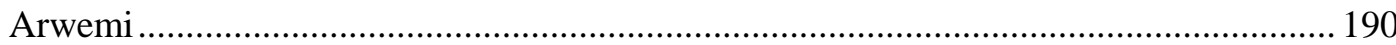

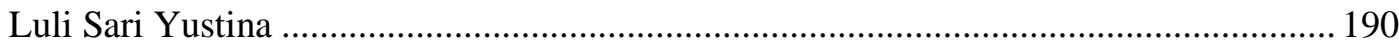

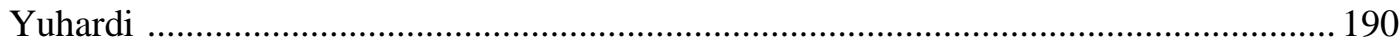

AUTHENTIC MATERIAL: HOW DO I MOTIVATE MY STUDENTS IN ESP

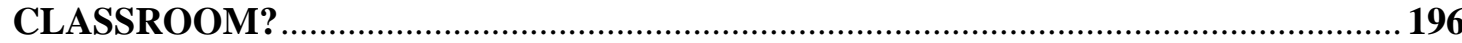

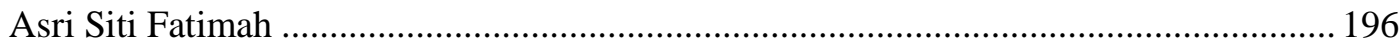

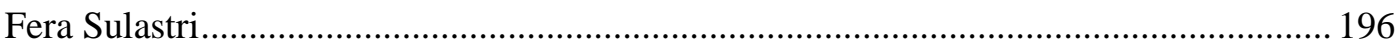

STORYTELLING VS. SPEAKING COMPETENCE: CONTEXTUALIZATION ON

SPEAKING SKILL BY APPRECIATING LITERARY WORKS ............................... 201

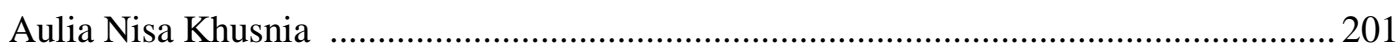

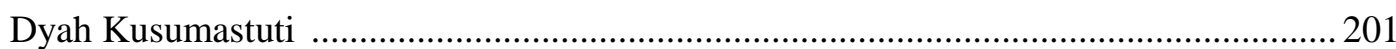

HELPING STUDENTS WRITE NARRATIVE TEXTS USING SMS (STORY

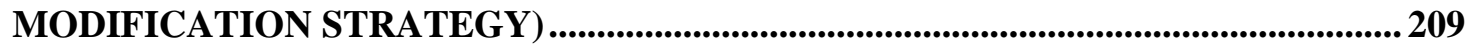

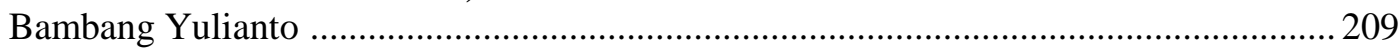

STUDENTS' PORTFOLIOS THROUGH WINDOWS MOVIE MAKER IN

EVALUATING ORAL PERFORMANCE IN SPEECH CLASS ................................219

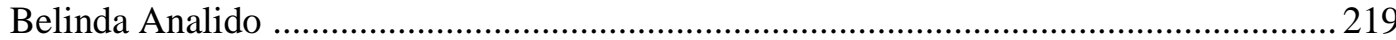

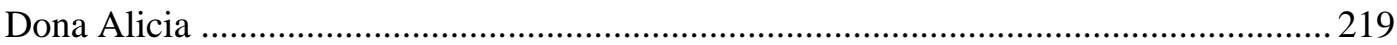

EMPLOYING SELF-REFLECTIVE VIDEO IN FOSTERING STUDENTS'

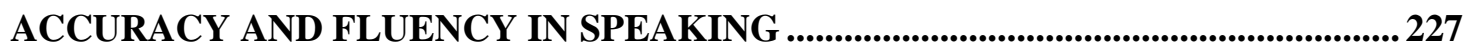

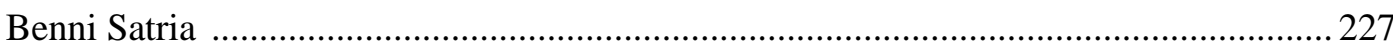

AN ANALYSIS OF TEACHERS' BELIEFS TOWARD AUTHENTIC MATERIALS IN

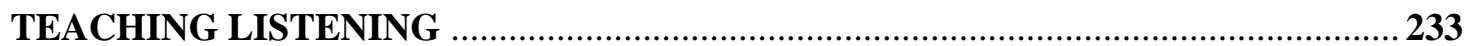

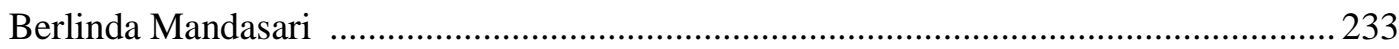

MICROSOFT ONE NOTE IN EDUCATION AS A TECHNOLOGICAL TOOL TO

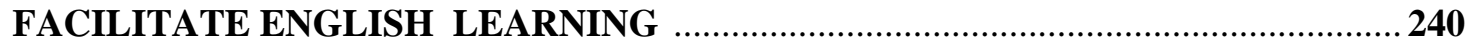

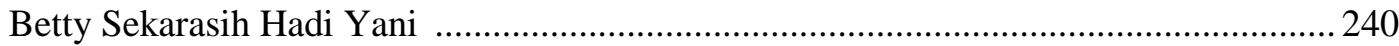

DEVELOPING PICTURE-BOOKS BASED LOCAL FABLE FOR EIGHT GRADE

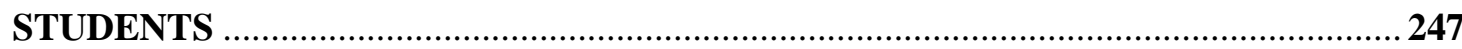

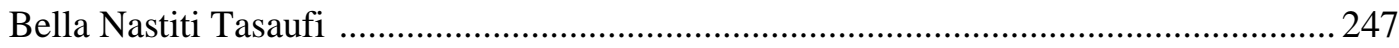

CONTRIBUTING FACTORS FOR L2 GRAMMAR DEVELOPMENT ON EFL

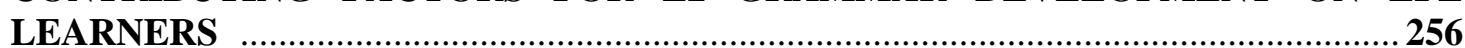

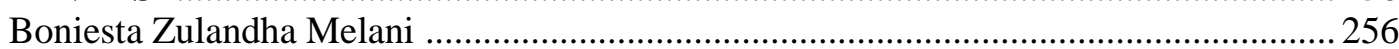

HOW TO USE 3H (HERE, HIDDEN, IN MY HEAD) IN TEACHING NARRATIVE

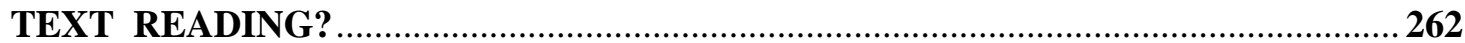

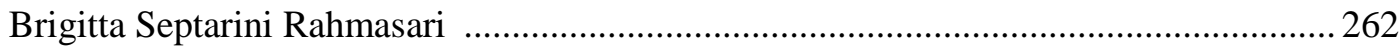

MICRO-EVALUATION OF WRITING MATERIALS DESIGNED BY STUDENT TEACHERS OF LANGUAGE EDUCATION:

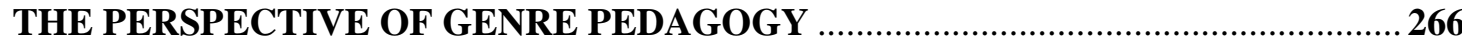

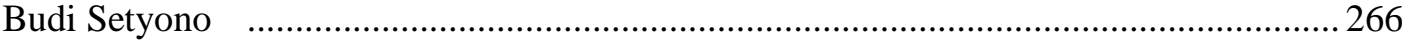

THE PATTERN OF TEACHER INSTRUCTION AND FUNCTION OF

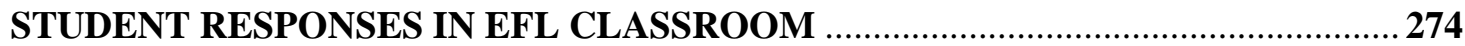

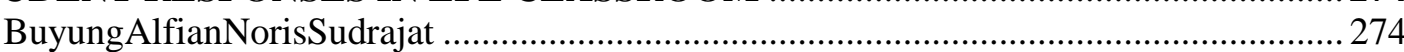

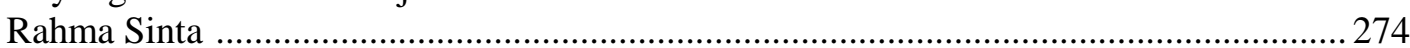


FLIPPED CLASSROOMIN TEACHING SPEAKING TO YOUNG

LEARNER

Choiril Anwar

Aswan Pratama

COMPARING THE EFFICACY OF VIDEO LISTENING TEST VERSUS AUDIO

LISTENING TEST FOR EFL STUDENTS

Clara Herlina Karjo

COLLABORATIVE ELT LEARNING THROUGH SOCIAL NETWORK

THE LANGUAGE APPROACH TO WRITING LANGUAGE TEACHING MATERIALS THROUGHOUT THE WORLD

EXTENSIVE READING ACTIVITIES IN TEACHING READING FOR FOREIGN

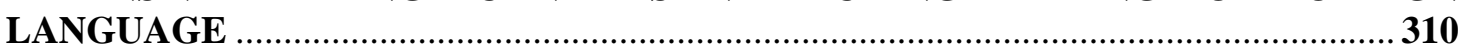

Dani Safitri

Leo Candra Wahyu Utami

310

PROTOTYPING MULTI-TRAIT SCORING RUBRICS AND CAN-DO STATEMENTS ON WRITING COMPETENCE: ANCHORING GRASS ROOTS' VOICE TO THEORETICAL GROUNDS AND GLOBAL FRAMEWORK …………..................316

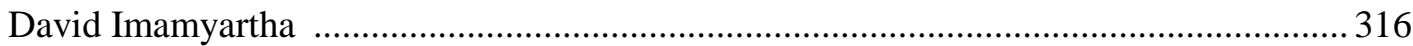

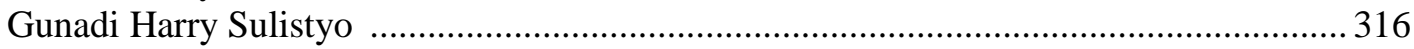

REVISITING THE USE OF GENRE-BASED INSTRUCTION FOR TEACHING

WRITING: FROM TEACHING EVALUATION TO MATERIAL

DEVELOPMENT .

Debora Tri Ragawanti

STUDENTS' NEEDS OF ENGLISH SPEAKING MATERIAL AT FPBS IKIP

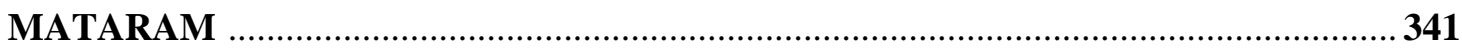

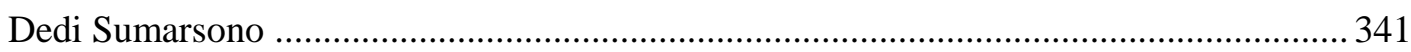

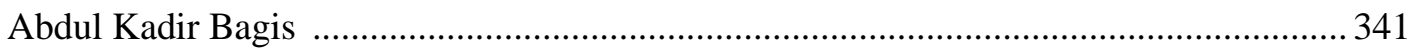

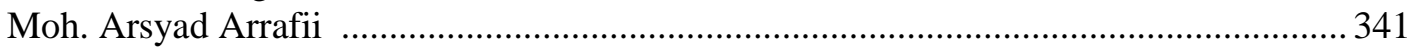

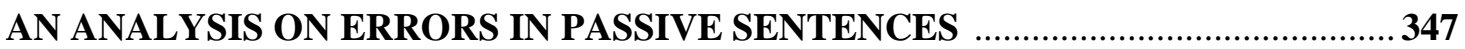

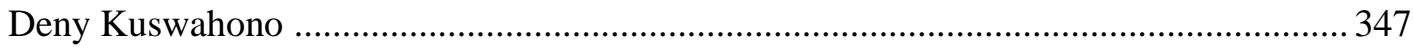

HOW GRAMMAR TEACHING ENHANCES ACCURACY AND FLUENCY: REVEALING PERSPECTIVES OF INDONESIAN GRADUATE

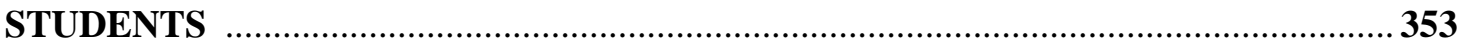

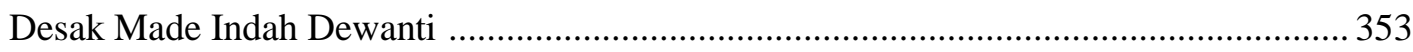

IMPLEMENTING BACKWARD DESIGN IN ENGLISH FOR SPECIFIC PURPOSES (ESP) SYLLABUS FOR SHIPBUILDING POLYTECHNIC .......................................358

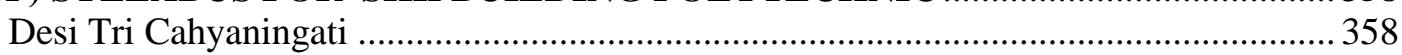

WRITING PERSONAL LETTER USING IRREGULAR VERBS APP FOR

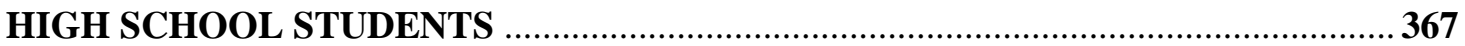

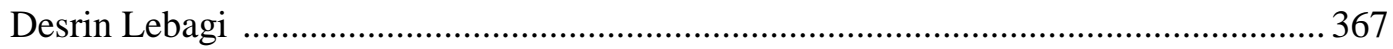

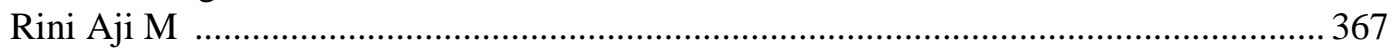

THE USE OF LANGUAGE ARTS IN ENGLISH TEACHING AND

LEARNING

Dessy Dwi Yudha Santhi 
STUDENTS' PERCEPTIONS ON THE USE OF SCHOOLOGY IN PRESENTATION CLASS

ACTIVATING STUDENTS' MOTIVATION IN SPEAKING CLASS THROUGH THE USE OF BOARD GAME AT ENGLISH DEPARTMENT OF MULAWARMAN

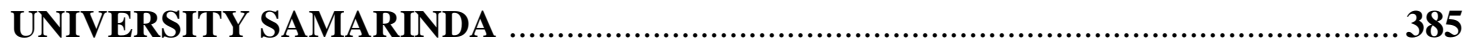

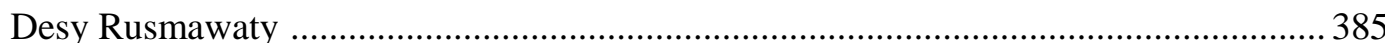

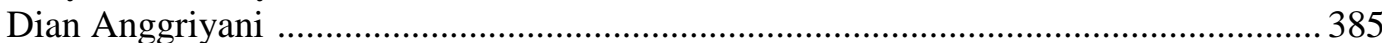

METHOD, STRATEGY AND PROBLEMS IN TRANSLATION FOR THE BEGINNER AT DIPLOMA' S CLASS IN SBC MENGANTI, GRESIK ……................. 391

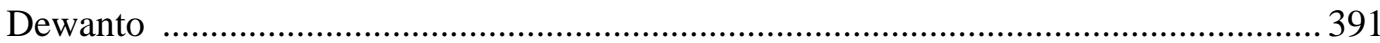

MAXIMIZING AUTHENTIC ASSESSMENT FOR TEACHING SPEAKING …........ 397

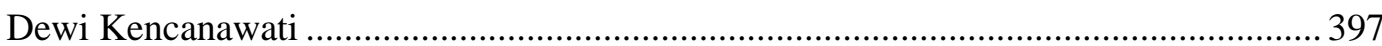

MASTERCHEF" VIDEO SERIES AS A MEDIUM TO TEACH SPEAKING

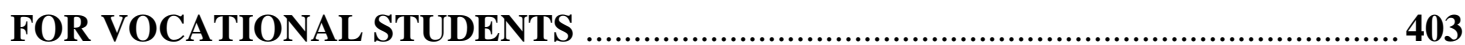

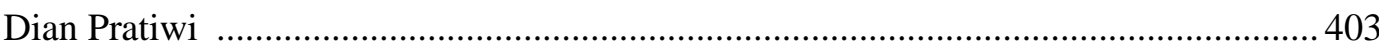

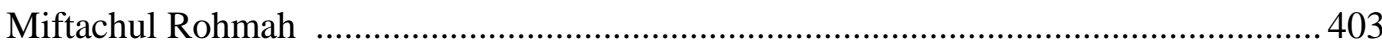

LEARNING COMMMUNITY BETWEEN ENGLISH TEACHER-LECTURER TO DEVELOP INSTRUCTIONAL MATERIALS FOR JUNIOR HIGH SCHOOL STUDENTS

DIRECTING DIVERGENT THINKING APPROACH FOR PRE-SERVICE ENGLISH TEACHERS' INTEGRATED

LEARNIN

Didik Rinan Sumekto

HOW DO PROFESSIONAL EFL TEACHERS DEVELOP THEIR TEACHING

MATERIALS?

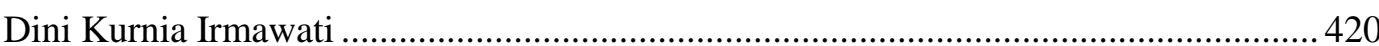

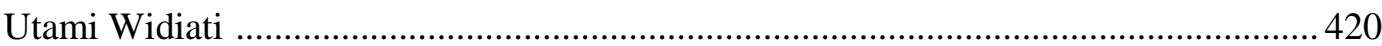

PRACTICING THE STUDENTS' PRONUNCIATION AND ADDING VOCABULARY IN INTENSIVE ENGLISH CLASSES BY PLAYING THE TABOO

GAME

Dini Noor Arini

THE COLLABORATION OF TEACHER - STUDENTS ASKING GOOD QUESTION IN REDUCING CODE SWITCHING AND CODE MIXING OF EFL

CLASS

Diyah Atiek Mustikawati

DESIGNING MATERIALS AND THE IMPLEMENTATION OF METHODOLOGY FOR BUSINESS ENGLISH FOR MAGISTER MANAJEMEN STUDENTS IN

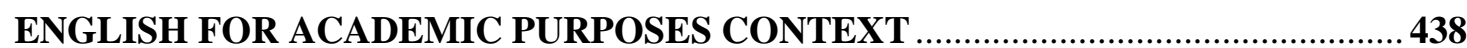

Djasminar Anwar

INTEGRATING E-LECTURES BLENDED WITH PROBLEM BASED LEARNING ACTIVITIES

USING STORY DIFFERENT ENDING CHOICES TO ENRICH STUDENTS

'LITERATURE OVERVIEW IN EXTENSIVE READING CLASS 
THE USE OF INFORMATION TECHNOLOGY AS THE MEDIA TO BOOST THE

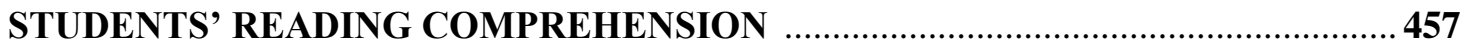

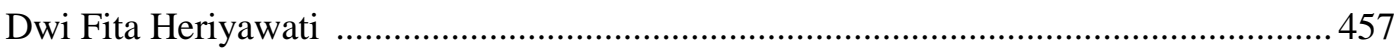

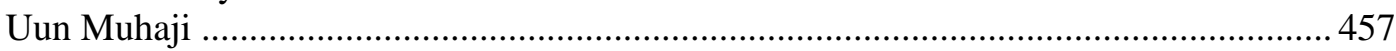

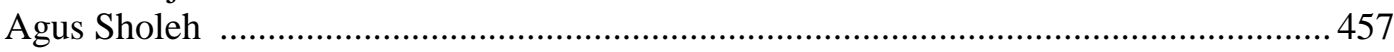

TRANSLATION QUALITY OF ENGLISH INTO INDONESIA SIMPLE SENTENCE

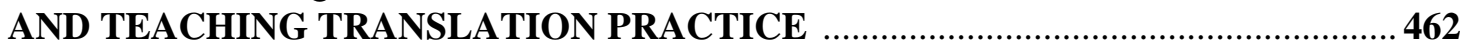

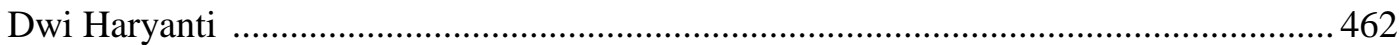

Siti Fatimah 462

TEACHING VOCABULARY BY USING MEDIA WORDWALL OF PROJECTOR IN THE THEME "PEOPLE AND THEIR PHYSICAL APPEARANCES" TO THE SEVENTH GRADE STUDENTS OF MTSN MODEL 2 PALEMBANG …….............467

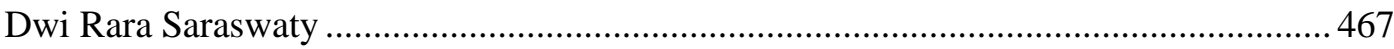

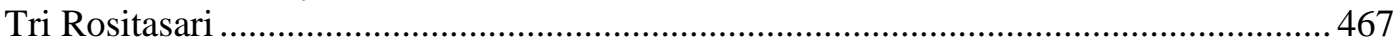

THE PHILOSOPHY OF SH TERATE AS LOCAL WISDOM IN TEACHING

SPEAKING FOR VOCATIONAL SCHOOL STUDENTS .......................................473

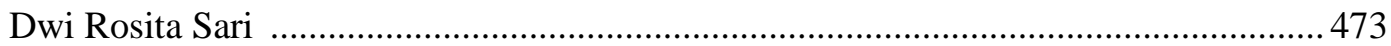

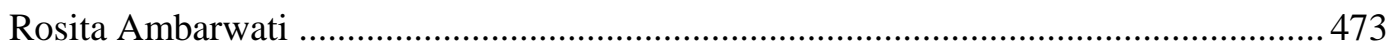

SELF- REGULATED LEARNING AND SELF EFFICACY BELIEFS OF PRESERVICE TEACHER PROFESSIONAL DEVELOPMENT ……..............................477

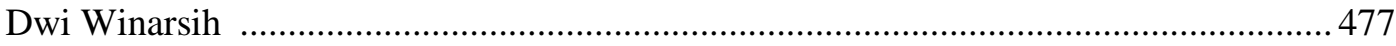

INTERNET-BASED MATERIALS IN TEACHING WRITING:
HOW DOES IT WORK?

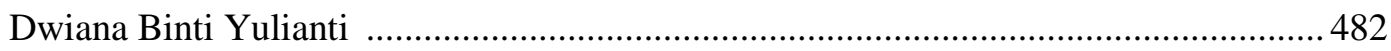

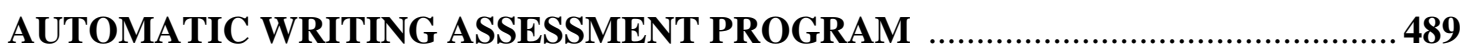

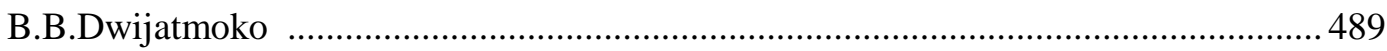

VIDEO RECORDING-BASED PEER FEEDBACK IN MICROTEACHING

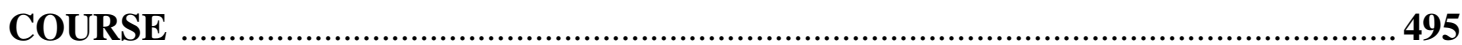

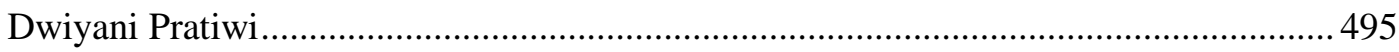

WHY SHOULD I DO SUMMARIZING?: THE VOICE OF UNDERGRADUATE

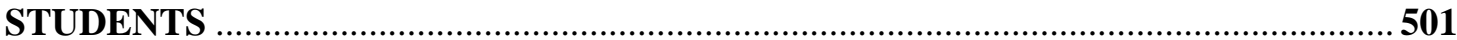

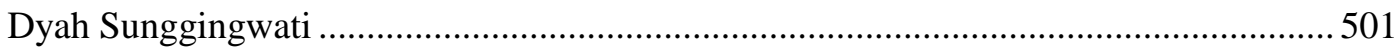

DESIGNING AND DEVELOPING SUPPLEMENTAL TECHNOLOGYINTEGRATED TEACHING, LEARNING AND MATERIALS OF POWERPOINT, AUDACITY, CAMTASIA AND INTERNET (PACI) MODEL THROUGH BLENDED

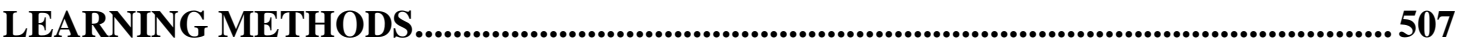

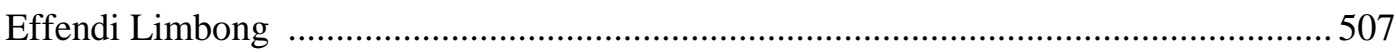

MOBILE-ASSISTED LANGUAGE LEARNING AS A DIGITAL MEDIA IN A FOREIGN LANGUAGE TEACHING: FOSTERING STUDENTS' LISTENING .......523

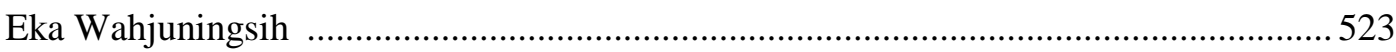

THE EFFECT OF COGNITIVE STYLES AND VOCABULARY MASTERY TO READING COMPREHENSION (AN EXPOST FACT RESEARCH AT UNIVERSITY

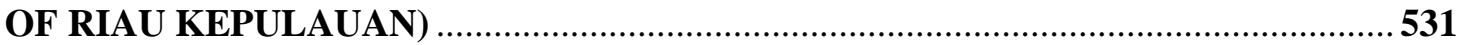

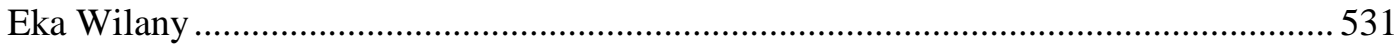

SMALL CLASSES OF ENGLISH LANGUAGE LEARNING IN UNIVERSITY

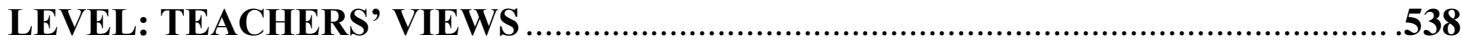

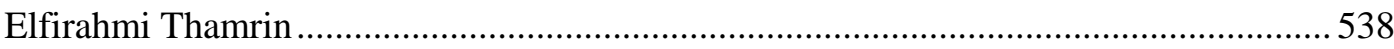

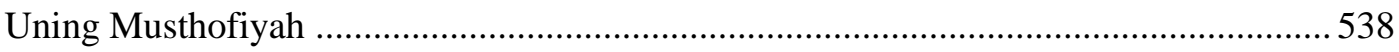


THE IMPLEMENTATION OF QUIPPER SCHOOL AS EXTENDED ENGLISH

LEARNINGIN SMA NEGERI 1 SOOKO, MOJOKERTO .......................................545

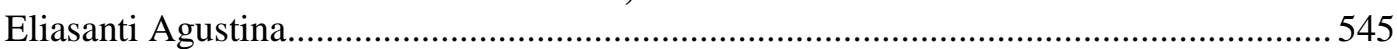

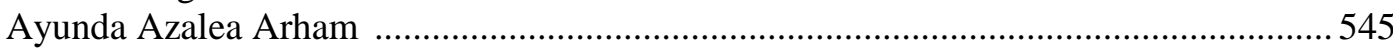

AN ESP PROJECT WORK FOR ENGINEERING FACULTY: BOOSTING

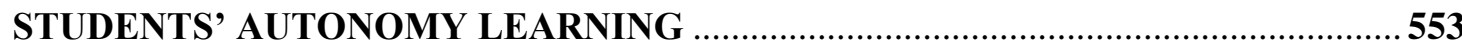

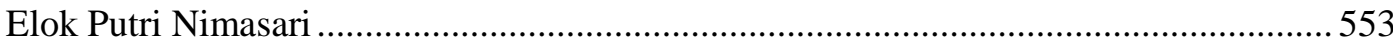

DEVELOPING INSTRUCTIONAL DESIGN TEACHING MATERIAL BASED

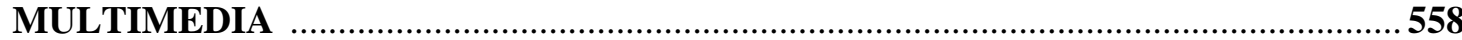

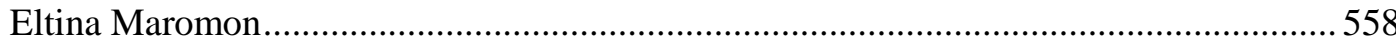

AN OBSERVATION OF APPLYING ACTIVE LEARNING IN AN EFL CLASS: A CASE STUDY OF TEACHER OF STUDENT VIEWS ON LEARNING ENGLISH AT SAO PEDRO SCHOOL DILLI, TIMOR LESTE

Elvis Fernandes Brites da Cruz 562

DESIGNING ACADEMIC WRITING FOR ESP STUDENTS

Emilia Ninik Aydawati .573

THE USE OF GLOSSING TECHNIQUE TO ENHANCE THE ESP LEARNERS

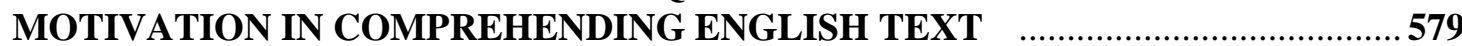

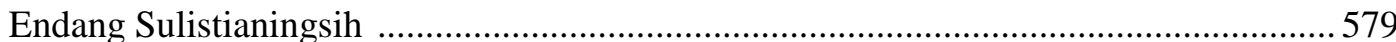
Sumartono 579

THE IMPLEMENTATION OF JEOPARDY STRATEGY OF EFL STUDENTS OF STKIP YPUP 587

Eny Syatriana 587

THE EFFECT OF EXPERIENTIAL LEARNING IN ESSAY WRITING TOWARDS

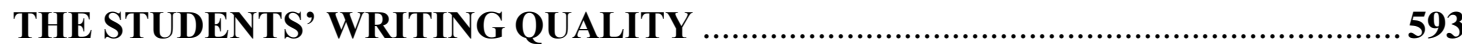

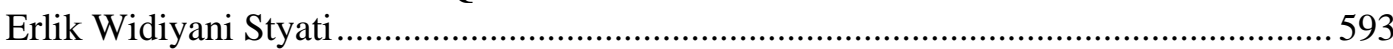

IMPROVING STUDENTS' READING COMPREHENSION BY USING QUESTIONS TOURNAMENT AT THE SECOND GRADE OF SMP …...................................59 Eroh Muniroh 598

IMPROVING STUDENTS' READING COMPREHENSION THROUGH

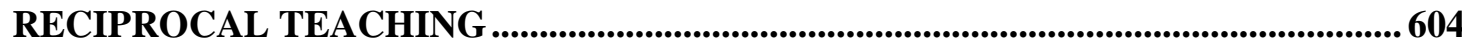

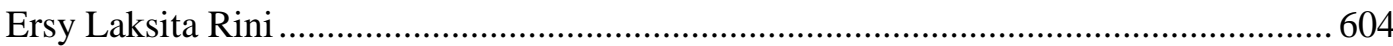

DOCUMENTARY VIDEO PRESENTATION: AN EFFECTIVE WAY OF

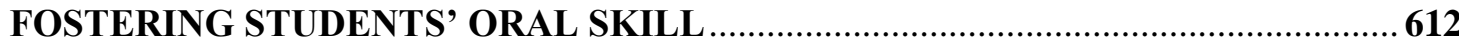

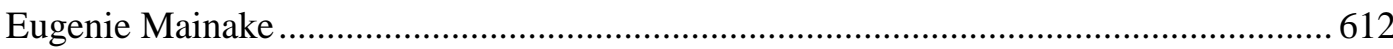

PROJECT-BASED LEARNING IN PRACTICE: THE PRODUCTION OF

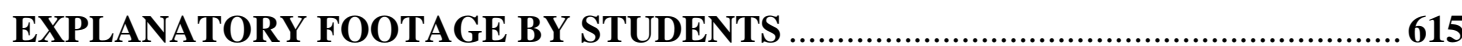

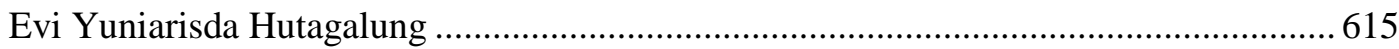

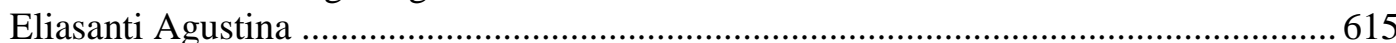

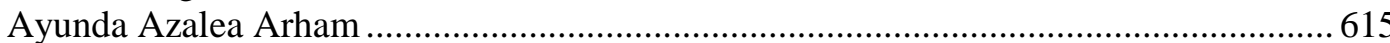

DIGITAL STORYTELLING IN WRITING: PRACTICE AND PERCEPTION TOWARD TEACHING WITH TECHNOLOGY ..................................................626 Faiqotur Rizkiyah 626

IMPROVING PRE-SERVICES ENGLISH TEACHERS' PEDAGOGICAL COMPETENCIES IN INTERNSHIP PROGRAM...................................................635

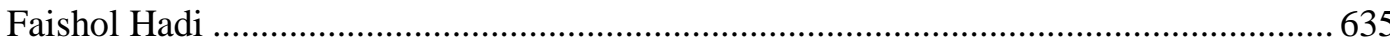

MOBILE ASSISTED LANGUAGE LEARNING: THE RECENT APPLICATIONS OF EMERGING MOBILE TECHNOLOGIES .....................................................................6.6.6. 641

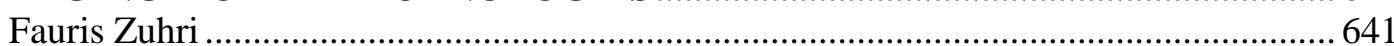

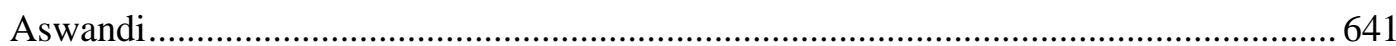


DEVELOPING INTERPERSONAL INTELLIGENCES IN SPEAKING

CLASS THROUGH THEMATIC BASED LEARNING .............................. 657

Fibriani Endah Widyasari.................................................. 657

ANDROID BASED EDUCATIONAL GAME IN INDONESIAN TEYL............ 662

Fika Megawati ................................................................... 662

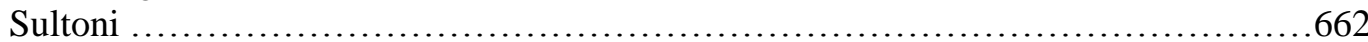

IMPROVING STUDENTS' ABILITY IN ACADEMIC WRITING

THROUGH EXPLICIT TEACHING …....................................... 669

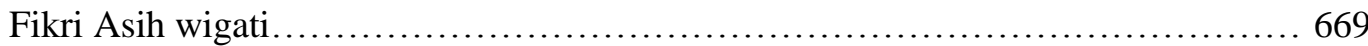

Nina Puspitaloka ............................................................. 669

THE INFLUENCE OF IMAGINE, ELABORATE, PREDICT, AND CONFIRM

STRATEGY AND READING INTEREST ON READING COMPREHEN-

SION ACHIEVEMENT OF THE SECOND SEMESTER STUDENTS OF

BIOLOGY EDUCATION STUDY PROGRAM, MUHAMMADIYAH

UNIVERSITY OF PALEMBANG............................................. 673

Finza Larasati .............................................................. 673

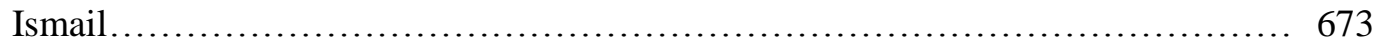

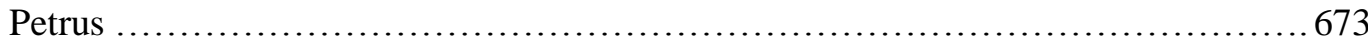

STUDENTS' VOICE TOWARD TEAMS-GAMES-TOURNAMENTS

TECHNIQUE................................................................. 683

Firman Wicaksono........................................................ 683

BUILDING LANGUAGE AND CULTURAL AWARENESS: MOVIES AS

POETRY AND CREATIVE PEDAGOGY DISCUSSION RESOURCE ............. 689

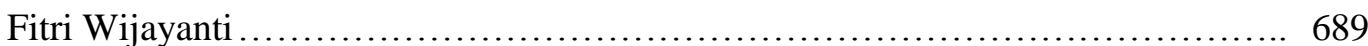

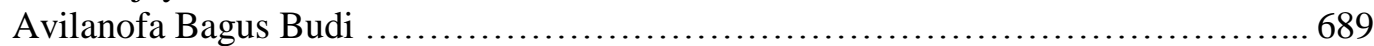

STUDENT-TEACHER PARTNER DESIGN: ENRICHING TEACHER

CREATIVITY AND CHALLENGING STUDENTS' INVOLVEMENT …....... 695

Fitrotul Mufaridah....................................................... 695

MUSEUM AS MEDIA AND SOURCE OF HISTORY LEARNING OF

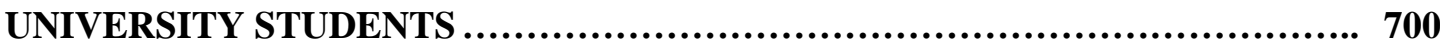

Franciscus Xaverius Wartoyo ................................................. 700

IS BACKGROUND KNOWLEDGE IMPORTANT IN ASSESSING

READING COMPREHENSION? ...................................................... 707

Fransisca Endang Lestariningsih ............................................ 707

THE USE OF ORAL CORRECTIVE FEEDBACK FOR STUDENTS OF

DIFFERENT PROFICIENCY LEVELS ...................................... 712

Gartika Pandu Bhuana ................................................... 712

A SET OF ENGLISH INSTRUCTIONAL MATERIALSUSING TASK-BASED LEARNINGFOR NEWS PRODUCTION MANAGEMENT STUDY PROGRAM

IN STMM "MMTC" YOGYAKARTA............................................ 721

Giovanna Gistha Wicita..................................................... 721 
THE USE OF TECHNOLOGY (BLOG) AS TEACHING MEDIA TO ENCOURAGE STUDENTS CHARACTERS TOWARD LEARNING ............................ 730

Gusti Nur Hafifah................................................... 730

USING STORYTELLING VIDEO FOR ASSESSING STUDENT'S CREATIVITY IN

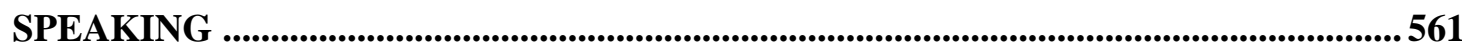

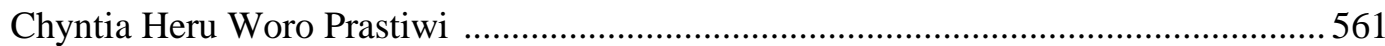

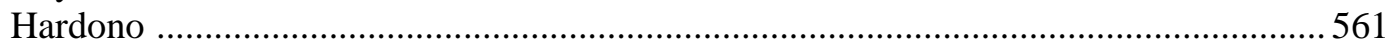

THE ROLE OF "MAGIC BOX" IN INNOVATING MEDIA IN TEACHING

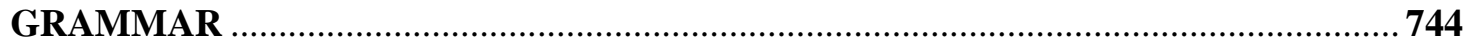

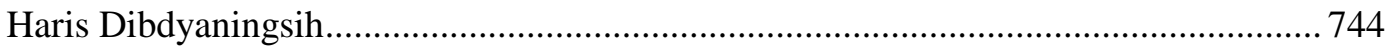

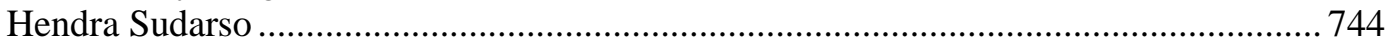

RESPONDING THE PRESENCE OF WORLD ENGLISHES IN TEACHING EIL

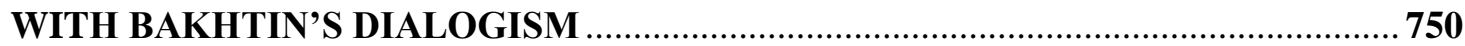

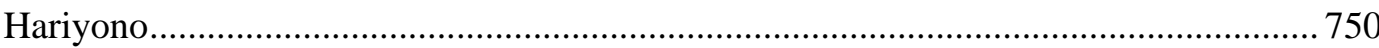

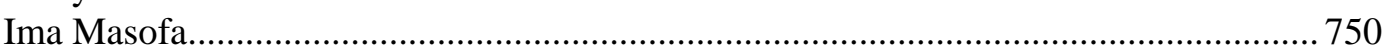

COMPARING THE USE OF 2 INTERNET BASED PLATFORMS TO SUPPORT FLIPPED CLASSROOM STRATEGY AT HIGHER EDUCATION INSTITUTES IN

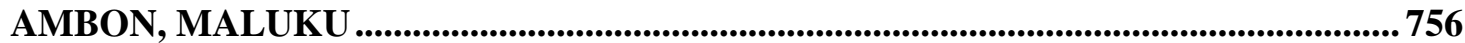

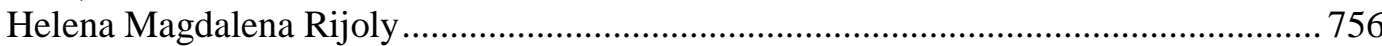

TEACHER'S EFFORT TO DEVELOP THEIR STUDENTS' EQUAL

PARTICIPATION IN ENGLISH SPEAKING CLASS ............................................764

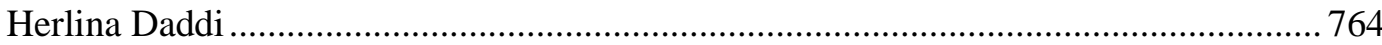

THE USE OF MOTIVATIONAL STRATEGIES BY EFL PRIMARY

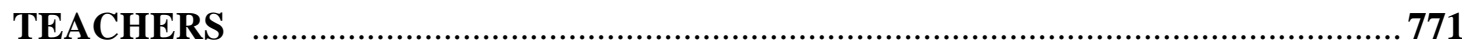

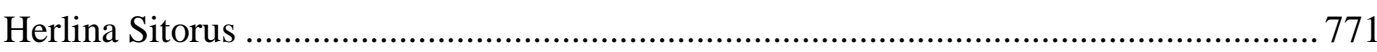

LEARNING STYLES' IMPLICATIONS TO LEARNING AND TEACHING ENGLISH

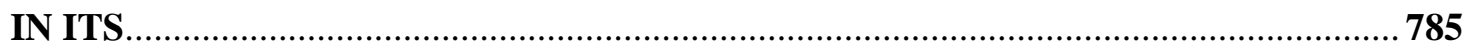

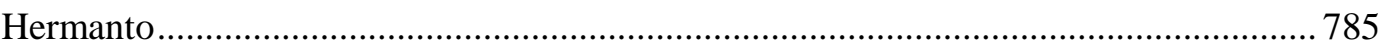

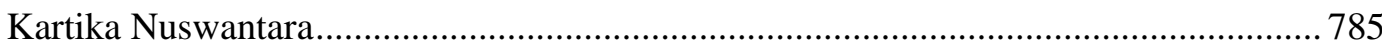

BLENDED LEARNING IN ELT FOR TEACHERS' CONTINUING PROFESSIONAL

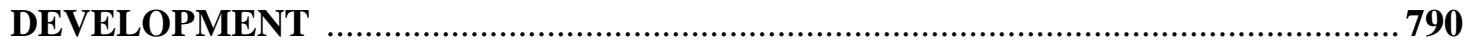

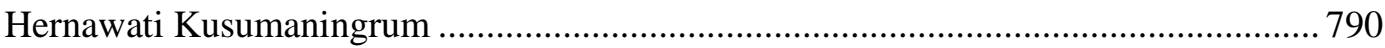

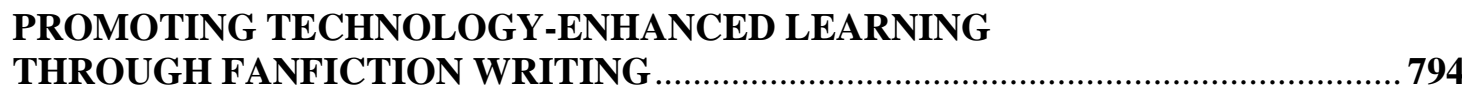

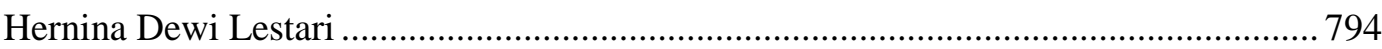

ACTION RESPONSE THROUGH THE USE OF TRANSLATED VERSION OF

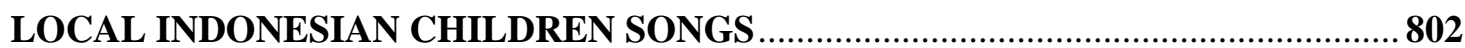

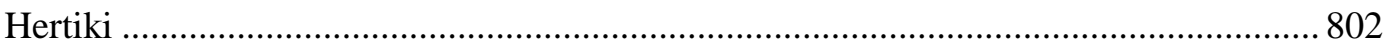

THE PROSPECT OF ENGLISH FOR SPECIFIC PURPOSES MATERIALS DEVELOPMENT FOR EIGHT MAIN DISCIPLINES AHEAD OF ASEAN INTEGRATION:

CRITICAL EVIDENCE ACROSS ASEAN MEMBER COUNTRIES ….........................805

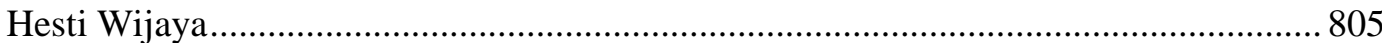

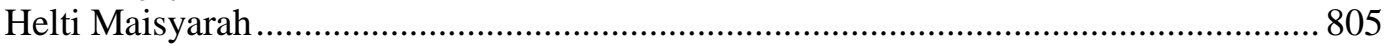

TEACHERS' MEDIA IN TEACHING ENGLISH AT JUNIOR HIGH SCHOOL IN

PADANG 
A NEEDS ANALYSIS FOR DESIGNING AN ESP-BASED SYLLABUS IN AN

ISLAMIC STUDIES EDUCATION PROGRAM ...............................................................820

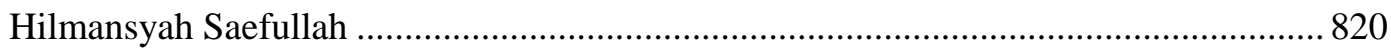

THE EFFECT OF EXTRA-CURRICULAR ACTIVITY ON THE STUDENTS'

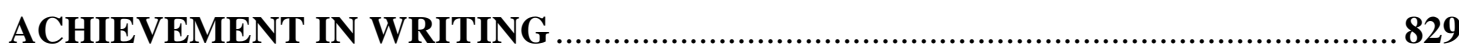

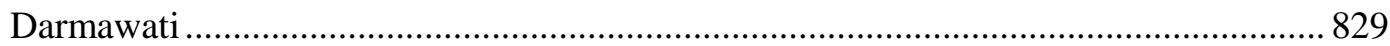

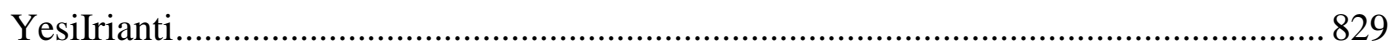

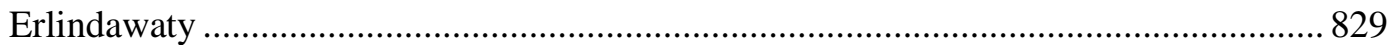

FOLKLORE TO ENHANCE THE STUDENTS' MOTIVATION (INNOVATION IN

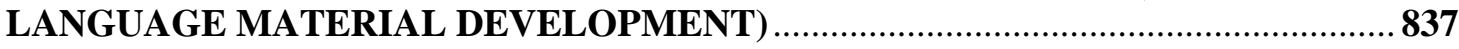

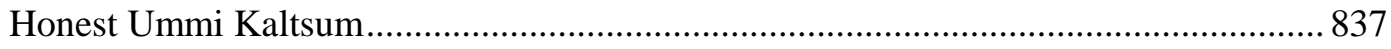

THE PROFICIENCY OF TEACHERS IN TEACHING BIOLOGY BY USING

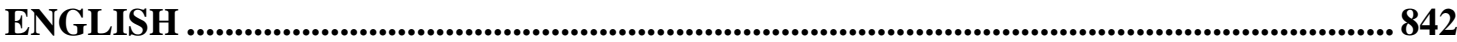

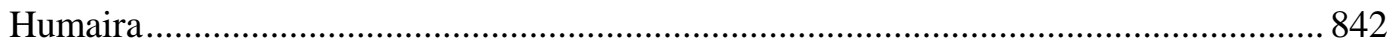




\title{
THE ROLE OF "MAGIC BOX" IN INNOVATING MEDIA IN TEACHING GRAMMAR
}

\author{
Haris Dibdyaningsih \\ harisdibdyaningsih@gmail.com \\ STKIP Al Hikmah Surabaya, Surabaya, Indonesia \\ Hendra Sudarso \\ STKIP PGRI Bangkalan, Bangkalan, Indonesia
}

\begin{abstract}
Innovative way in teaching L2 learners can be considered as a challenging job while it can be facilitated by using "Magic Box" as a tool box consists of many stationeries and reuse things to innovate new interactive media. The main purpose of this study was conducted to identify the role of "Magic Box" in innovating interactive media in teaching grammar. The samples participants of the study were 24 students of English Department of STKIP Al Hikmah Surabaya. They were chosen because of they have low grammar score, so they should develop their grammar understanding. The lecture will guide and show to the students how to innovate interactive media using "Magic Box". This study was designed as a quantitative study with pretest and post-test instruments allow lectures to empirically evaluate the role of "Magic Box" in innovating interactive media in learning grammar by the students through formative assessment. After analyzing the pre-test and post-test it was found that using "Magic Box" has the important role in teaching grammar to the students. Furthermore, "Magic Box" has its potential as a tool box for innovate interactive media, be able to motivate students and trigger the students to be more creative in innovating interactive media to improve their grammar understanding.
\end{abstract}

\section{Keywords: "Magic Box", interactive media, pre and post-test}

\section{INTRODUCTION}

In learning English there are main four skills that links each others, they are listening, speaking, reading, and writing. In order to communicate well in those four skills, learners need to acquire several important grammars that must be differing in certain occasion. Grammar also important to accomplish any requirement test when the students have to go abroad or when they want to continue their study abroad, grammar understanding also improtant for their daily application because some grammar apply for distinguish time of events. Therefore grammar is an important part in learning new language.

When students are trying to understand a grammar, sometimes they get bored and need some tools that can help them to improve their grammar understanding. Therefore the lecture modifies some tools and asks the students to create interactive media to reduce their boredom. This study was set to discover the effects of 'Magic Box' on language learning on the aspect of grammar understanding, whether it possible learners to improve their grammar understanding and enjoy the learning process at the same time.

'Magic Box' is a box that consist many stationeries, flannel cloth and simple tools that can help students to create an interactive media. The tools are such as color markers, pencil, tapes, many types of pen, glue, colorful papers, rulers, cutters, crayons, etc.

Interactive media which can create using 'magic box' are media that can be used to explain a lesson based on the theme. In example, the lesson is about present tense, and then students make a miniature of a fish. Each student in the class will make one miniature and describe it in front of the class, the miniature help students to explain a thing using present tense. This study use pre test and post test due to examine the students' grammar understanding development. The tests consist of fill in the blank task about Prepositions of place, preposition of time, including in/on/at, Present continuous, and Present simple. which given before and after using 'Magic Box' as teaching tool. Wright, Betteridge and Buckby (2005) stated that language 
learning is very hard and efforts are required over a long period of time. Special attention is given to the problems related teaching and learning grammar.

In addition, a review on the importance of innovating interactive media to make language learning enjoyable and trigger students to apply their creativity is provided. Learners of new language have to deal with grammar during their acquisition. In order to learn and retain new words, learners should participate in different task-based activities in their classroom whether it is interactive game, describing things, memorizing task and conversation exercise. Such activities also include grammar media which especially focus on helping learners develop and use grammar in different contexts by making the class enjoyable.

Therefore, it is necessary to explore whether students learn grammar effectively through interactive media and how they learn it. Normally students memorize the grammar's rule in a list, and when they fail with this method, they will say that it is caused by their bad memorization. Research and publications have shown that this is not a very effective way to study. Ozmen (2004) expected to discuss a way of strengthening the awareness and through learning and self - esteem in adult language classes. 'Magic Box' is designed to help students built their self-esteem.

Learning English can be facilitating by many different tools. One of the learning tool that is used in STKIP AL HIKMAH is 'Magic Box' that seems have positive effects on learners' grammar. Thus this study was conducted to identify how 'Magic Box' may facilitate the teaching process and help students to learn grammar. And it has tried to find out whether 'Magic Box' can improve learners' grammar process as well as identifies the potentiality of using 'Magic Box' for creativity training.

\section{METHOD}

Since our study is concerned with grammar development, quantitative instruments; pre and post tests are utilized in the beginning and at the end of the study. Based on Skjåk \& Harkness (2003), the significance of implementing these instruments in a research is regarded to the reason that pre and post test data can show a difference in scores that can be measured for significance. They also highlighted that the use of pre-test and post-test instruments allows instructors a unique opportunity to empirically evaluate the effectiveness of their instruction and assess the acquisition of course content material by students through determining assessment.

The participants for this study were 24 students in of STKIP AL HIKMAH SURABAYA. The samples of the study were 20 students who are needed to improve their grammar's understanding.

In this study, firstly a pre-test was given to 24 students to a) determine the pretest score b) find a criterion based on which to place the students in either control and treatment (experimental) group. Out of 24 students who took the pre-test, we excluded 4 of them who could get the highest score in which seem that they have totally high level of language and the grammar's understanding.

Later it can be seen in Table 1, the scores of other 20 students were classified in groups of $15(0-15,15-30,31-45,46-60,61-75)$ then the students whose scores were in each group were divided into two equal groups as control and experimental so that, the students were distributed in each group similarly.

Table 1: Classification into Control group (Cg) and Experimental group (Eg) based on pre-test scores.

\begin{tabular}{|c|c|c|}
\hline Scores & Number of students in Cg. & Number of students in Eg. \\
\hline $0-15$ & 2 & 1 \\
\hline $16-30$ & 1 & 2 \\
\hline $31-45$ & 5 & 4 \\
\hline $46-60$ & 2 & 3 \\
\hline $61-75$ & 0 & 0 \\
\hline $76-100$ & 0 & 0 \\
\hline Total & 10 & 10 \\
\hline
\end{tabular}


As it can be seen in Table 1 the other 20 students were classified into two groups either control or experimental. Control group consisted of 10 students and they had normal teaching lessons while the treatment group consisted of another 10 students and apply a different teaching method that is using 'Magic Box' as a tool to teach specific grammars. The duration of the study was five lessons while the two mentioned groups were given the same amount of time with the same amount of targeted grammars to learn but through the different methods of teaching.

\section{Instruments}

Three research instruments were used to collect data for this research, namely the pre-test, 'Magic Box' and post-test. Since this study was small scale, using the three instruments for data collection would help to validate the findings; the findings from all the instruments could converge to present the result of this research. Data gathered from the pre and post test were counted and tabulated to make comparison of achievements of the students. Later analyses were done accordingly.

\section{Pre-Test:}

The pre-test was given to the students at the beginning of the research where the students had poor level of grammar's understanding. Both groups had the same test. The test consisted of 50 simple task of fill in the blank exercise where the students have to divine appropriate grammar for each sentence given. The duration of 1 hour was given for the students to complete the test. The scores were recorded for comparison and analyses.

\section{'Magic Box'}

The 'Magic Box' is a box that consists of many stationeries and simple tools that can be used to create interactive media. The stationeries are such as, colour pencils, colour markers, several colours of flannel cloth, plastic glue, colourful papers, hammer, pliers, etc. 1 'Magic Box' will be used for 3 or 4 students. Students have to make a media using 'Magic Box', and explain a grammar rule using the media. For instance, a students have to explain about present tense, and then he make a car miniature and describe the car using simple present tense. Furthermore, every media that made by the students help the students to directly apply a grammar rule and explain it in front of the class. So every students have to be creative in create new interactive media to help them in grammar understanding development.

\section{Post Test}

The post test was the same as the pre-test and was given to all students from both groups. The purpose of the post test was to see whether the students are able to master the grammar's understanding targeted for them. The scores were recorded for comparisons and analysis.

\section{Data Analysis}

After collecting data and placing the students into two groups of control and experimental group the researcher started to analyze the data. The data analyses of this study were done based on the frequency counting method and the findings were recorded in two phases. The first one was done as soon as the pre- test was over. The scores were recorded and tabulated for easy reference of comparison later. The second phase was done right after the post test took place. Again, the scores were recorded and tabulated for the purpose of comparison too.

Most importantly, after the post test, the improvement was carefully calculated and converted into percentage to be used in the discussion of findings later. All these numbers were presented in the forms of tables so that the reader could have easy comprehension of the pre-test scores, the post test scores and the improvement of the students. It was convenient for the readers to compare and contrast and see what the researcher meant as the improvement were counted and converted into percentage, so that the readers did not have to make their own calculation and reading was smooth and undisturbed. 


\section{FINDINGS AND INTREPRETATION}

The research findings were analyzed in accordance with the research problem. As it can be seen in Table 2, most of the students (10\%) in both control and experimental group obtained the score of 0 to 10 in pre-test which is the lowest score, while no $(0 \%)$ students gained higher score.

Table 2: Pre-test in percentage

\begin{tabular}{|c|c|c|}
\hline Scores & $\begin{array}{c}\text { Number of students of } \\
\text { Control Group in percentage }\end{array}$ & $\begin{array}{c}\text { Number of students of Experimental } \\
\text { Group in percentage }\end{array}$ \\
\hline $0-15$ & $20 \%$ & $10 \%$ \\
\hline $16-30$ & $10 \%$ & $20 \%$ \\
\hline $31-45$ & $50 \%$ & $40 \%$ \\
\hline $46-60$ & $20 \%$ & $30 \%$ \\
\hline $61-75$ & $0 \%$ & $0 \%$ \\
\hline $76-100$ & $0 \%$ & $0 \%$ \\
\hline & $100 \%$ & $100 \%$ \\
\hline
\end{tabular}

After applying the use of 'Magic Box' in experimental group for the students of three groups, a post test was taken. The result of the post test is tabulated in Table 3 and Table 4.

Table 3: Post test of control group

\begin{tabular}{|c|c|c|}
\hline \multirow{2}{*}{ Score } & \multicolumn{2}{|c|}{ Control group } \\
\cline { 2 - 3 } & No. of students & No. of students in percentage \\
\hline $0-15$ & 1 & $10 \%$ \\
\hline $16-30$ & 2 & $20 \%$ \\
\hline $31-45$ & 2 & $20 \%$ \\
\hline $46-60$ & 1 & $10 \%$ \\
\hline $61-75$ & 4 & $40 \%$ \\
\hline $76-100$ & 0 & $0 \%$ \\
\hline Total & 10 & $100 \%$ \\
\hline
\end{tabular}

Table 4: Post test of experimental group

\begin{tabular}{|c|c|c|}
\hline \multirow{2}{*}{ Score } & \multicolumn{2}{|c|}{ Experimental group } \\
\cline { 2 - 3 } & No. of students & No. of students in percentage \\
\hline $0-15$ & 0 & $0 \%$ \\
\hline $16-30$ & 0 & $0 \%$ \\
\hline $31-45$ & 1 & $10 \%$ \\
\hline $46-60$ & 1 & $10 \%$ \\
\hline $61-75$ & 4 & $40 \%$ \\
\hline $76-100$ & 4 & $40 \%$ \\
\hline Total & 10 & $100 \%$ \\
\hline
\end{tabular}

As you can see in Table 3 and Table 4, all the students in the experimental group show encouraging improvements comparing those in control group. None of the students in the experimental group scored less than forty five while in control group again, there are students who got score less than forty five.

Based on the findings above, it was clearly that 'Magic Box' benefits the students in the experimental group in their grammar's understanding development compared to controlled group. The findings showed that 'Magic Box' is teaching learning tool that able to make student improve their grammar understanding as well as their creativity.

It was found that the learning environment for the experimental group is more excited and lively. The students were enthusiastic and even the quiet and passive ones were also drawn into the activity using 'Magic Box'. The lessons on innovate interactive media using 'Magic Box' proved that students improve their creativity and their grammar understanding. The findings to a certain extend indicated that 'Magic Box' holds the potential as an effective education tool for creativity training. 
In addition, the researcher found that the other positive effect of using 'Magic Box' in teaching grammar to the students is that the 'Magic Box' gives opportunity for the students to be creative and innovative. They were independent and were able to create their own interactive media. Furthermore, the elements of creativity to innovate interactive media made them learn faster implicitly. On the other hand, the controlled group was dominated by the lecture and the students were told what to do. The lesson were fully developed and directed by the lecture using textbook-based approach. The students only did what they were told. Here, students were totally dependent on the lecture for input resources and there were no room for self development and fun. On top of that, findings show that the experimental group improved more than the controlled group.

Moreover, the experimental group reveals a higher degree of improvement especially for the Low English Proficiency (LEP) and shy students. In this lessons the 'Magic Box' used allowed the LEP and passive students to participate and be active. The High English Proficiency (HEP) and LEP students were working together in groups also incorporated good moral values as well as encouraging positive peer learning. Thus, this result explains the higher improvement of experimental group as compared to the controlled group. In the controlled group, only the HEP students will benefit as they dominated the lessons most of the time and left the LEP to struggle on their own.

Another observation which was worth noticing was the noise level during both treatments. During the controlled group lesson, the students made noise which was tolerable. The lecture played minimal role in controlling the class. However, during the experimental group lesson the noise level was high. Students were seen chatting at each other and moving about here and there. Yet, the environment was controllable because the students need to be attentive to the lecture's instructions.

Moreover, another obvious observation is the willingness of the students to try and not afraid of making mistakes among the experimental group which is one of the essential factors for the learning and making interaction and conversation with other learners without stress and anxiety in relation to speech out. This important point is very worth to mention that most of students have behaviour problem and they shy when they tend to speak in front of the active students and who they are comfortable students they are afraid of laughing and mocking from their friends. But it is observed that by using of 'Magic Box' as a learning tool, the students have to make the media in group they have done same as the other friends. During the controlled group lessons, the students were willing to try when they were asked to do so. Students were reluctant to make mistakes. This was noticed when questions were asked during the controlled group lesson, nobody volunteered. When a student was called, the student referred to friends for discussion. In contract, the experimental group participants were willing to try. The even managed to delegate tasks by assigning certain individuals to certain words. Discussions to decide which kind of tool was suitable or not were carried out.

Perhaps the most motivating factor in students' participation was the competitive of innovate interactive media. Students might not participate actively during normal lesson as there was no pressure to create new interactive media. Meanwhile, in the experimental group the students had strong desire to participate actively and even encourage the shy classmates to innovate interactive media.

\section{CONCLUSIONS AND SUGGESTION}

The conclusions were drawn related to the research problem of the study about how 'Magic Box' may facilitate the teaching process and help students to learn grammar understanding. And it has tried to find out whether 'Magic Box' can improve learners' grammar understanding as well as identifies the potentiality of using 'Magic Box' for creativity training. The conclusions were: (1) All participants from the experimental group show different levels of improvement in their grammar understanding using 'Magic Box' based on their scores in the pre-test and post test; The different levels of improvement among the learners in the experimental group reflect that some learners benefit more from the 'Magic Box'; (2) Participants in the controlled group comparatively show less improvement in grammar understanding through the usual classroom teaching practice; (3) 'Magic Box' has its potential as an educational tool for creativity training; (4) 'Magic Box' can motivate and engage learners 
especially the quiet and passive ones in the whole learning process; (5) It is proved that 'Magic Box' can give a good opportunity to the shy students to be active and from psychology aspect they will show and improve their hidden abilities; (6) Being enjoy and happy is important factor in children learning; because of this fact, 'Magic Box' is a good tool for drawing them to the enjoyable and happy learning process, as it has showed in the researches the students, even adult can remember every details of any subject and event when they face it visually and truly.

\section{SUGGESTION}

The followings are suggestions for further studies: (1) As 'Magic Box' are effective tools to teach grammar, it is to suggest that further studies on the use of 'Magic Box' to teach the language skills of listening, speaking, reading and writing to be carried out. (2) The use of computer drawing media tools in educational training is another area that is worth exploiting. (3) Lectures should not confine themselves to the use of 'Magic Box' tool for classroom practices. There are many other types of teaching tools that can be used to improve students' language skills.(4) Lectures should allow the students to create and modify their innovation media using 'Magic Box'.

\section{REFERENCES}

Ozman, K. (2004) . "Make them Be Aware, Not Beware of learning" Asian EFL Journal. File:///Cl/asian-efl-journal/asianefljournal/04-kso.html

Skjåk, K. K., \& Harkness, J. A. (2003). Data collection methods. In J. A. Harkness, F. J. R. Van de Vijver, \& P. P. Mohler (Eds.), Cross-cultural survey methods (pp. 179-193). Hoboken, NJ: John Wiley \& Sons.

Wright, A., Betteridge, D., \& Buckby, M. (2005). Games for language learning (3rd ed.). New York: Cambridge University. 